\title{
Climate since AD 1510 on Dyer Plateau, Antarctic Peninsula: evidence for recent climate change
}

\author{
L. G. ThOMPSON, \\ Byrd Polar Research Center, The Ohio State Lniversity, Columbus, OH 43210, U.S.A. \\ D. A. PEEL, \\ British Antarctic Survey, Natural Environment Research Council, Cambridge CB3 OET, England
}

E. Mosley-Thompson,

Byrd Polar Research Center, The Ohio State University, Columbus, OH 4.3210, U.S.A.

R. Mllvaney,

British Anlarclic Surzey, Natural Environment Research Council, Cambridge CB3 OET, England

J. DAI, P. N. LiN, M. E. DAVIS,

Byrd Polar Research Center, The Ohio State University, Columbus, OH 43210, U.S.A.

C. F. RAYMOND

Geophysics Program, University of Washington, Sealle, WA 98195, U.S.A.

\begin{abstract}
ABSTRACI. A 480 year record of the oxygen-isotope ratios, dust content, chemical spccies and net accumulation from ice cores drilled in 198990 on Dyer Plateau in the Antarctic Peninsula is presented. The continuous analyses of small (subannual) samples reveal well-preserved annual variations in both sulfate content and $\delta^{18} \mathrm{O}$, thus allowing an excellent time-scale to be established.

This history reveals a recent pronounced warming in which the last two decades have been among the warmest in the last five centuries. Furthermore, unlike in East Antarctica, on Dycr Plateau conditions appear to have been fairly normal from $A D$ I500 to 1850 with cooler conditions from 1850 to 1930 and a warming trend dominating since 1930. Reconstructed annual layer thicknesses suggest an increase in net accumulation beginning early in the 19th century and continuing to the present. T'his intuitive conflict between increasing net accumulation and depleted $\delta^{18} \mathrm{O}$ (cooler climate) in the 19th century appears widespread in the peninsula region and challenges our understanding of the physical relationships among moisture sources, air temperatures and snow accumulation. The complex meteorological regime in the Antarctic Peninsula region complicates meaningful interpretation of proxy indicators and results in a strong imprint of local high-frequency processes upon the larger-scale climate picture.
\end{abstract}

\section{INTRODUCTION}

A co-operative glaciological climatological ice-core drilling program was conducted on Dyer Plateau $\left(70^{\circ} 40^{\prime} 16^{\prime \prime} \mathrm{S} ; 64^{\circ} 52^{\prime} 30^{\prime \prime} \mathrm{W} ; 2002 \mathrm{~m}\right.$ a.s.l.; mean annual temperature: $-21^{\circ} \mathrm{C}$ ) between 1988 and 1992. The program draws upon the expertise of each group to establish a 480 year paleoenvironmental history of the Antarctic Peninsula region (Fig. 1). In 1988-89, a geophysical program was initiated and two ice cores were drilled to a depth of $108 \mathrm{~m}$ at a location $6 \mathrm{~km}$ west of the divide. In 1989 90, two cores were recovered $1 \mathrm{~m}$ apart on the crest of Dyer Plateau (core $1-233.8 \mathrm{~m}$ and core $2-235.2 \mathrm{~m}$ ) and two $50 \mathrm{~m}$ cores were drilled $4 \mathrm{~km}$ cast of the divide. In 1989-90, the geophysical measurements were expanded to encompass the new core locations as well as potential future drill sites (paper in preparation by C. Raymond and others). Ice-corc quality varied from excellent (long, continuous pieces) in the upper $112 \mathrm{~m}$ to very poor (fractured and wafered) below: $190 \mathrm{~m}$. The history presented here is from the top $112 \mathrm{~m}$ of core 1 (AD 1761-1990) and the lower part (112-190 m) of core 2 (AD 1504-1760). The complementary sections of both cores are being analyzed at the British Antarctic Survey (BAS) as part of this joint project.

The Antarctic Peninsula area is a climatically complex and sensitive region which extends northward across the cirum-polar trough (Schwerdtfeger, 1984). This is a 


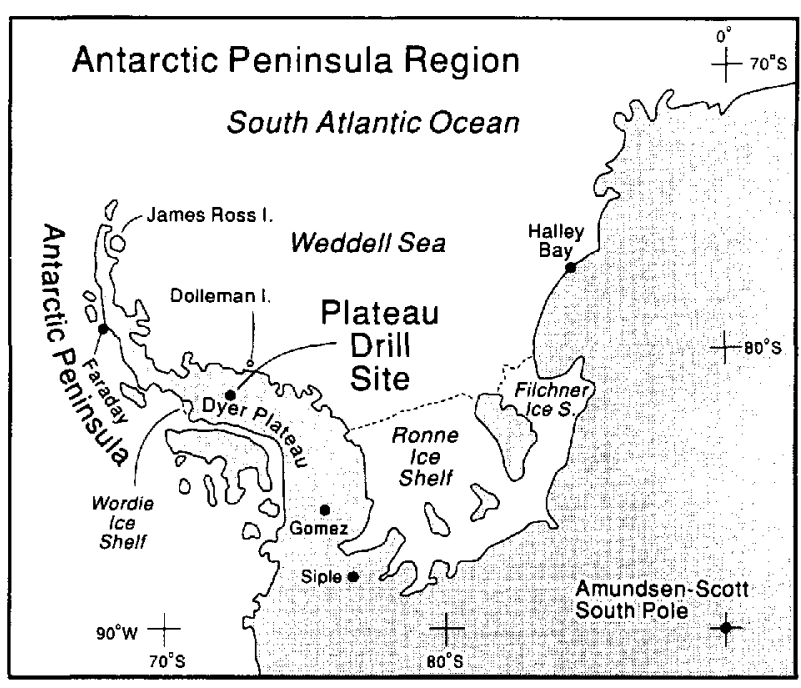

Fig. 1. The location of the Dyer Plateau drill site in the Antarctic Peninsula region is illustrated along with other geographic features mentioned in the text.

major area for sca-ice production and thus meteorological conditions are strongly affected by variations in sea-ice cover over the adjacent occans and the Weddell Sea. This project is part of a continuing effort to construct a global climate synthesis for the last 1000 years with special emphasis upon the character and temporal synchroneity of the "presumed" most recent Neoglacial event often called the "Little Ice Age" (LIA)". Identifying and understanding the linkages between climatic variations in lower latitudes and those in the polar regions should enhance our ability to identify and understand the mechanisms responsible for globally significant climate fluctuations. The Antarctic Peninsula is a key site for climatic and environmental reconstructions from ice cores and provides a critical link between records from the interior of Antarctica and those emerging from South Amcrica. First, a comprehensive climate history for the peninsula region must be reconstructed - a formidable task given the meteorological and oceanic complexity of the area.

\section{ICE-CORE ANALYSES}

Visual stratigraphy and density (Fig. 2) were measured immediately in the field. The borchole temperature profile was determined using two thermistors with calibration resistances at $0^{\circ},-15^{\circ},-30^{\circ}$ and $-50^{\circ} \mathrm{C}$. Borehole temperatures, measured 1 year after retrieval of the core, range from a minimum of $-21.36^{\circ} \mathrm{C}$ at $53 \mathrm{~m}$ to a maximum of $-19.89^{\circ} \mathrm{C}$ at $230 \mathrm{~m}$ (Fig. 2). All ice cores were returned frozen for physical and chemical analyses

\footnotetext{
* The term Little Ice Age (LIA) is controversial as the event has not been demonstrated to be global, although evidence of cooling does exist away from the North Atlantic where the LIA is a prominent feature in climate records. The term is useful as it generally indicates a cool period between $\approx A D 1500$ and 1900, although timing and intensity are quite variable.
}

in the laboratories at the Byrd Polar Research Center (BPRC) and the British Antarctic Survey.

Samples were cut continuously along the entire length of the core and each sample was analyzed for microparticle concentration (MPG) and size distribution, oxygenisotopic ratios $\left(\delta^{18} \mathrm{O}\right)$, liquid conductivity $(\mathrm{LC})$ and concentrations of selected inorganic anions. $\mathrm{MPC}, \delta^{18} \mathrm{O}$, LC and anions were measurcd at BPRC. All measurements except $\delta^{18} \mathrm{O}$ were conducted under Class 100 Clcan Room conditions. The concentration and size distribution of particles with diameters $\geq 0.63 \mu \mathrm{m} \mathrm{ml}^{-1}$ sample were measured using a model TA-II Coulter Counter (Thompson, 1977). Conductivity of liquid samples was measured with a Beckman model RC-16C conductivity bridge. The concentrations of the major anions of chloride (Cl), sulfate $\left(\mathrm{SO}_{4}{ }^{2}\right)$ and nitrate $\left(\mathrm{NO}_{3}\right)$ were detcrmined with a Dioncx model 2010 i chromatograph equipped with an AS4A anion separator column.

Total $\beta$ radioactivity is routinely used to identify known time-stratigraphic horizons associated with past atmospheric thermonuclear tests (Crozaz, 1969). Samples with masses between 250 and $350 \mathrm{~g}$ were cut from the upper $30 \mathrm{~m}$ of the core. These were acidificd, melted and pumped through ion-exchange filters, after which total $\beta$ radioactivity was measured by a Tennelec LB 1000 Series low-background $\beta$ counting system. When identified, these radioactive horizons allow verification of seasonally varying parameters and provide confirmation of the dating of layers younger than 1954 (Picciotto and Wilgain, 1963). Figure 3 illustrates the $\beta$ radioactivity profile along with $\mathrm{SO}_{4}{ }^{2}$ and $\delta^{18} \mathrm{O}$ for each sample in the upper $40 \mathrm{~m}$ of core 1 which encompass the last 53 years. Note that the first major incrcasc in $\beta$ radioactivity occurs in 1963-64, coincident with 1964 identified by counting annual variations in $\mathrm{SO}_{4}{ }^{2-}$ and $\delta^{18} \mathrm{O}$.

The high annual accumulation rate of $0.44 \mathrm{~m}$ (water equivalent) allowed each annual layer to be cut into an avcrage of 15 samples near the top and six samples at $181 \mathrm{~m}$. This sampling scheme resulted in 4136 samples

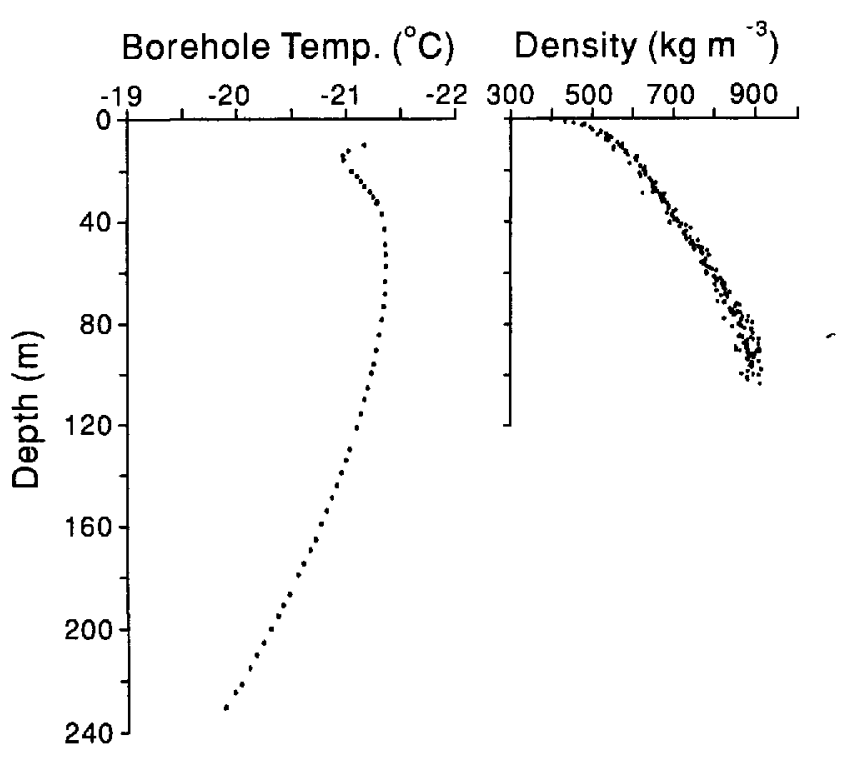

Fig. 2. The temperature profile was measured in the 1989 90 Dyer Plateau borehole and densities were measured lo $100 \mathrm{~m}$ along core 1. 


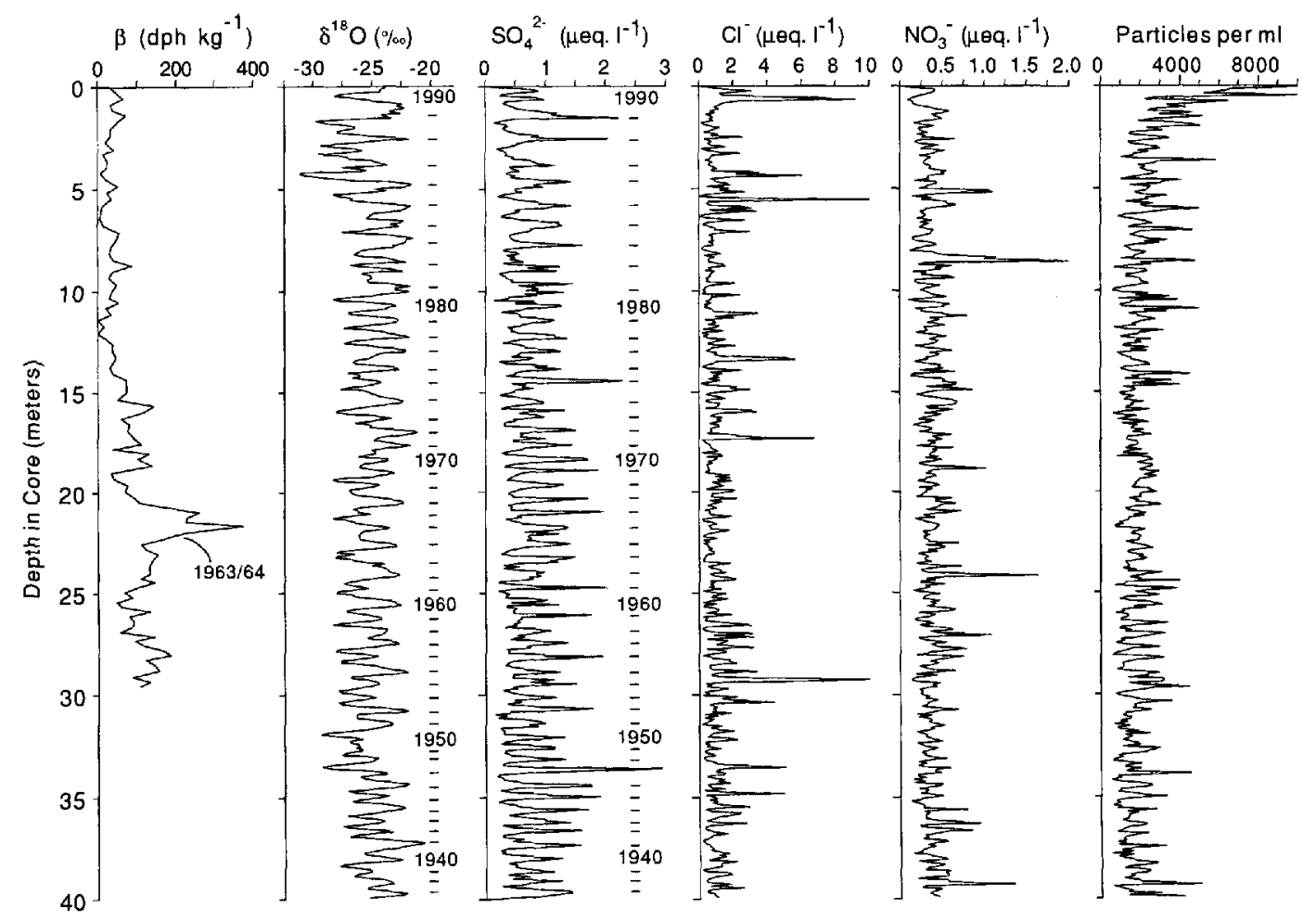

Fig. 3. The continuous analyses of $\delta^{18} \mathrm{O}, \mathrm{SO}_{4}{ }^{2}, \mathrm{Cl}, \mathrm{NO}_{3}$, and insoluble particulates (diameters $\geq 0.63 \mu \mathrm{m}$ ) are illustrated for the upper $40 \mathrm{~m}$ (1937-90) of core I on Dyer Plateau. The excellently preserved seasonal variations in $\delta^{18} \mathrm{O}$ and $\mathrm{SO}_{4}{ }^{2}$, confirmed by the 1963-64 $\beta$ horizon, provide a precise time-scale to $A D 1500$.

each for $\mathrm{MPC}$ and $\delta^{18} \mathrm{O}$ and 3850 samples for anions. These analyses reveal well-preserved, annual variations in both $\mathrm{SO}_{4}{ }^{2-}$ and $\delta^{18} \mathrm{O}$ which make dating the core straightforward. Figure 3 illustrates that $\mathrm{SO}_{4}^{2}$ shows the better seasonality than $\delta^{18} \mathrm{O}$ and the lack of welldefined scasonality in the concentrations of $\mathrm{Cl}^{-}, \mathrm{NO}_{3}{ }^{-}$ and dust content. Identification of known volcanic events (discussed later) lends further support to the time-scale. A precise time-scale is the first step in developing highresolution histories of atmospheric dust content, $\delta^{18} \mathrm{O}$, atmospheric chemistry and net annual accumulation.

\section{RESULTS}

As with any icc corc, these histories reflect a combination of local, regional and larger-scale processes. Of most interest are the regional and larger-scalc componcnts which ideally should be integrated with other Antarctic Peninsula histories to ascertain a broader picture of the climate history of the region. Comparing records from an array of sites also highlights spatial differences which may reflect more localized processes. A recent paper by Jones and others (1993) discussed the complexity of the meteorological regime in the peninsula region, the large spatial variability of climate parameters such as temperature and the mediocre relationship between $\delta^{18} \mathrm{O}$ and temperature $(\mathrm{R} \approx 0.5)$. The annual avcrages of $\delta^{18} \mathrm{O}$ from two Dyer Plateau cores, the $1989-90$ OSU core drilled at the plateau crest and the 1988-89 BAS core drilled $6 \mathrm{~km}$ west, arc illustrated in Figure 4. Included are the annual (August to the following July) average temperatures from Halley Bay, located on the coast to the east across the Weddell Sca. These three histories are smoothed with a 5 year Gaussian filter and reveal that in general the average $\delta^{18} \mathrm{O}$ records do capture much of the large-scale features of the temperature history at Halley Bay (see $R^{2}$ values given in Table 1). Jones and others noted the necessity to analyze additional cores from the peninsula and to include the analyses of both $\delta^{18} \mathrm{O}$ and $\delta \mathrm{D}$ in future studies.

The Dyer Plateau record presented here provides information from an additional site which is $6^{\circ}$ further south and $360 \mathrm{~m}$ higher than James Ross Island, 1600 and $870 \mathrm{~m}$ higher than Dolleman Island or the Gomez site, respectively, and $6.53 .5^{\circ} \mathrm{C}$ colder (annual average) than any other peninsula drill sitc (Pccl, 1992). At this time $\delta \mathrm{D}$ measurements have not been made but are planned in the near future.

Table 1. Coefficients of determination $\left(R^{2}\right)$ for a linear relationship among annually averaged $\delta^{18} O$ from two Dyer Plateau ice cores and mean annual temperatures at Halley Bay. All annual averages were smoothed with a 5 year Gaussian filler

\begin{tabular}{lccc}
\hline Parameter & $\delta^{18} \mathrm{O}-\mathrm{OSU}$ & $\delta^{18} \mathrm{O}-\mathrm{BAS}$ & $\begin{array}{c}\text { Halley } \\
T \mathrm{C}\end{array}$ \\
\hline$\delta^{18} \mathrm{O}-\mathrm{OSU}$ & 1.000 & 0.688 & 0.178 \\
& $(99.9 \%)$ & $(98.0 \%)$ \\
$\delta^{18} \mathrm{O}-\mathrm{BAS}$ & 1.000 & 0.413 \\
& & $(99.9 \%)$ \\
Halley $\left(T^{\circ} \mathrm{C}\right)$ & & 1.000 \\
\hline
\end{tabular}




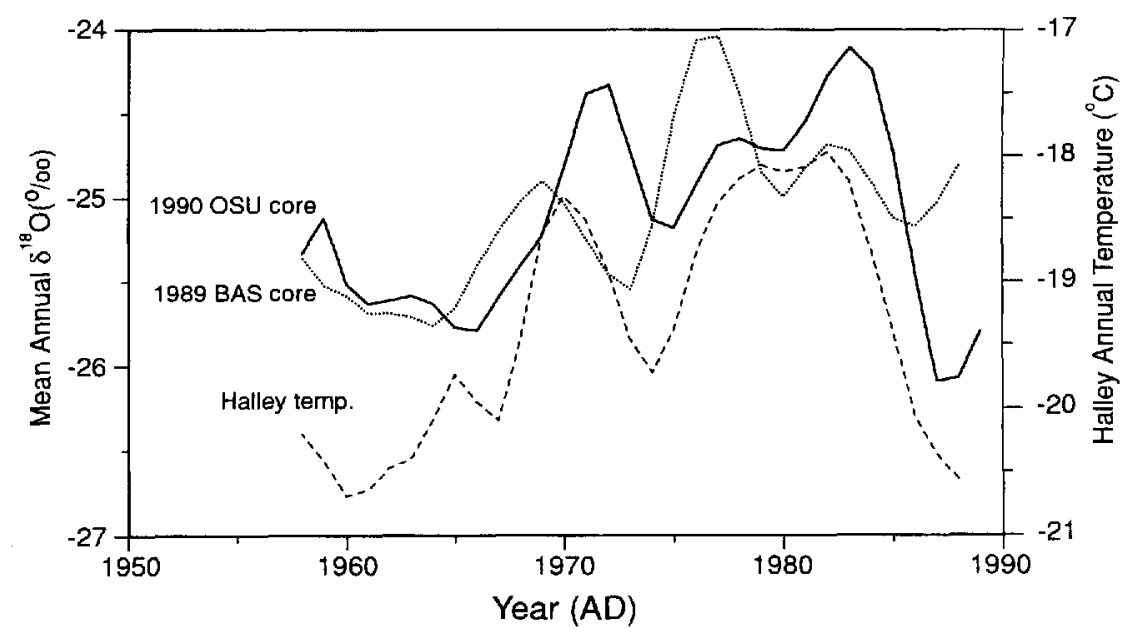

Fig. 4. The 1958-89 annual averages of $\delta^{18} \mathrm{O}$ from two Dyer Plateau cores, the 1989-90 OSU core and the 1988-89 BAS core, are compared with the annual average temperatures (August to the following 7 uly) from Halley Bay. All three records were smoothed with a 5 year Gaussian filter. The OSU core was drilled at the plateau crest and the BAS core was drilled $6 \mathrm{~km}$ to the west.

In 1985 a $302 \mathrm{~m}$ core was drilled at Siple Station $\left(75^{\circ} 55^{\prime} \mathrm{S}, 84^{\circ} 15^{\prime} \mathrm{W}, 1054 \mathrm{ma}\right.$ a.s.l.) at the base of the Antarctic Peninsula (Fig. 1). As on Dyer Plateau the excellent preservation of seasonal changes in $\delta^{18} \mathrm{O}$ and $\mathrm{SO}_{4}{ }^{2-}$ (Mosley-Thomson and others, 1991) provided a 550 year history of environmental conditions (MosleyThompson and others, 1990). To cxpand our view of the climate and environment of the peninsula area, the Dyer Plateau records are presented with comparable ones from Siple Station. This comparison highlights more regionally extensive trends dominated by larger-scale processes and also isolates diffcrences.

\section{Oxygen-isotopic analyses}

$\delta^{18} \mathrm{O}$ records reflect in varying degrees (1) the air temperature at which condensation occurs, (2) atmo- spheric processes occurring between the water-vapor source (occans) and the deposition site, (3) local conditions which dominate during firnification, and (4) the surface elevation and latitude of the depositional site (see Dansgaard and others, 1973; Bradley, 1985, for review). The correlation of atmospheric temperatures with $\delta^{18} \mathrm{O}$ and its spatial representativeness are still under discussion; nevertheless, $\delta^{18} \mathrm{O}$ is used widely as a climate proxy, particularly for temperature Jouzel and others, 1983; Thompson and others, 1986, 1989); Johnsen and others, 1992; Peel, 1992). As shown in Figure 4, the recent $\delta^{18} \mathrm{O}$ history appears to reflect the major temperature trends in the Weddell Sea sector (Table 1).

The decadal averages of $\delta^{18} \mathrm{O}$ for Dyer Plateau and Siple Station (Fig. 5) reveal the absence of a prolonged cool period from 1450 to 1850 , consistent with earlier $\delta^{18} \mathrm{O}$ histories from James Ross Island (Aristarain and

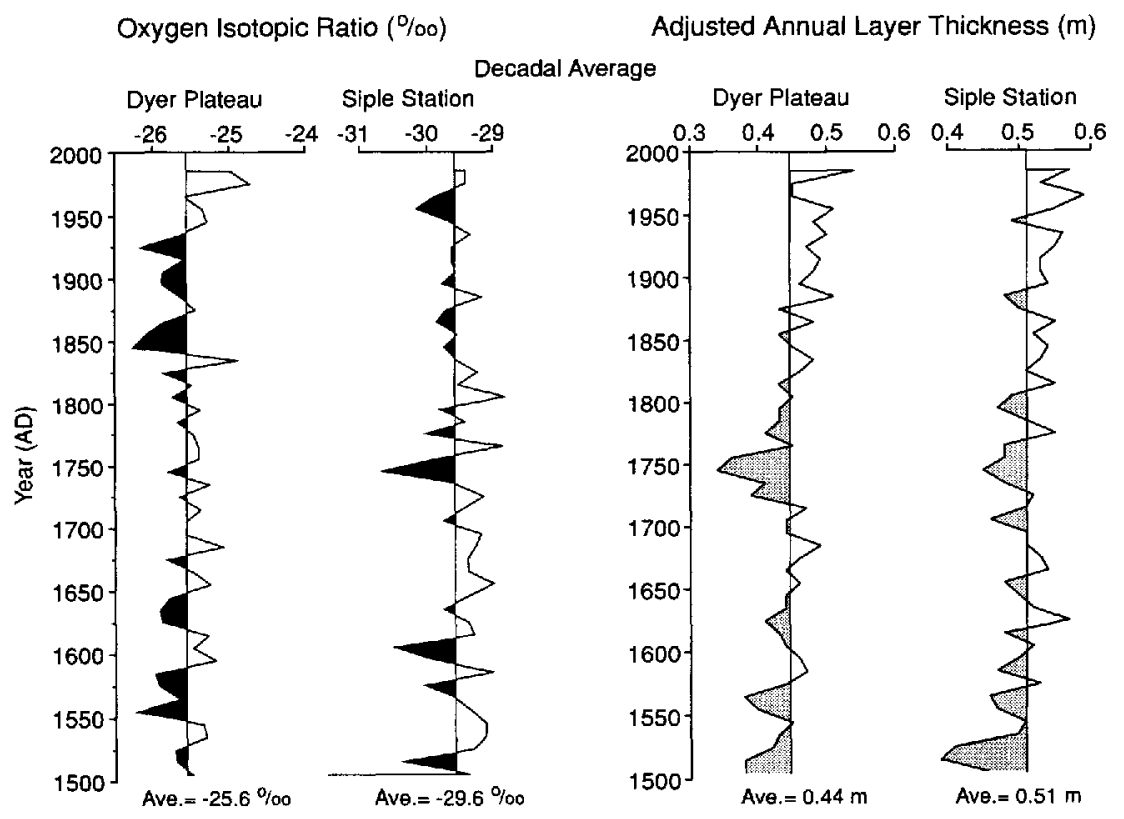

Fig. 5. Decadal anerages of $\delta^{18} \mathrm{O}$ and reconstructed layer thicknesses on Dyer Plateau are illustrated with concurrent histories from Siple Station located at the base of the Antarctic Peninsula. 
others, 1986) and Dolleman Island (Peel, 1992). This climate sccnario is different from that found in $\delta^{18} \mathrm{O}$ records from East Antarctica or from sites removed from the Weddell Sea sector (Mosley-Thompson, 1992) where coolcr than normal conditions were more prevalent prior to 1850 . The Dyer Plateau $\delta^{18} \mathrm{O}$ history suggests a marked cooling between 1840 and 1850 , after which cooler than normal conditions prevailed for a century. 'I'his centurylong cool period is not cvident at Siple Station at the base of the peninsula. On the other hand, the Siple Station $\delta^{18} \mathrm{O}$ record, like that from Dyer Plateau, reveals no prolonged cool period prior to 1850 (Fig. 5). The lack of a marked cool period on Dyer Plateau in the middle of the peninsula and at Siple Station, along with those from seteral lower-elevation, lower-latitude peninsula sites (Peel, 1992), provides an emerging view of the climate of the last half-millennium in the peninsula region which is quite different from that in Fast Antarctica. The Dyer Plateau $\delta^{18} \mathrm{O}$ record (Fig. 5) indicates an isotopic warming beginning in 1930 and extending to the present (the warming at Siple Station is more modest). On Dyer Plateau the last two decades have been among the "isotopically" warmest three decades the other being 183140 ) in the last five centuries. Instrumental records indicate that the warming since 1950 appears to be regionally significant throughout the peninsula. For example, from 1943 to 1992 temperatures at Faraday have warmed nearly $2.5^{\circ} \mathrm{C}$ (Jones and others, 1993). Further evidence of this warming is reflectcd in the rapid disintegration of the Wordie Ice Shelf from $\approx 2000 \mathrm{~km}^{2}$ in 1966 to $\approx 700 \mathrm{~km}^{2}$ in 1989 (Doake and Vaughan, 1991). Splettstoesser (1992) reported the recent retreat of Northcast Glacier on Stonington Island about 65 miles $[105 \mathrm{~km}]$ north of the Wordic Icc Shelf. These observations, along with $\delta^{18} \mathrm{O}$ (proxy) records, indicate a recent and continuing warming trend in the peninsula region.

\section{Annual layer thicknesses}

Annual laycr thickncsses provide a history of the net mass accumulating in a given year but do not reflect precipitation amounts directly. Unfortunately, layers thin as they are buried by subsequent accumulation and as they are stretched when the ice flows outward from the crest of the plateau. One objective of the complementary gcophysical study is to provide information about the flow characteristics of the ice around the borehole to adjust measured annual layer thicknesses for such thinning. One important assumption is that the surface vertical velocity is equal to the short-term accumulation rate of $1.16 \mathrm{~m} \mathrm{a}^{-1}$ mean density $=400 \mathrm{~kg} \mathrm{~m}{ }^{3}$ ) obtained from stake measurements for the period 1989 92. Another assumption is that the velocity and density profiles have remained constant over time. A detailed discussion of the final annual layer reconstruction is in preparation by $\mathbf{C}$. Raymond and others; however, the trend in these reconstructed thicknesses (Fig. 5) is not expected to change, although the final thicknesses may vary slightly.

Figure 5 illustrates the decadal averages of the reconstructed annual laycr thickncsses $\left(A_{n}\right)$ for both the Dyer Plateau and Siple Station cores. No long-term 480 year) trend is evident at either site, although several short-term (multi-decadal) trends appear to be synchro-
Table 2. Coefficients of determination $\left(R^{2}\right)^{*}$ are given for a linear relationship between measured ict-core constituents in a core from Siple Station and one from Dyer Plateau, Antarctica

\begin{tabular}{lcccc}
\hline Parameter & Particulates & $\delta^{18} \mathrm{O}$ & Excess $50 .^{2-}$ & $A_{\mathrm{n}}$ \\
\hline Particulates & $\begin{array}{c}0.475 \\
(99.9)\end{array}$ & & \\
& & 0.01 & \\
$\delta^{18} \mathrm{O}$ & & $\mathrm{NS}$ &
\end{tabular}

Excess $\mathrm{SO}_{4}{ }^{2-} \quad 0.583$

$A_{\text {n }}$

\footnotetext{
* $R^{2}$ indicates the fraction of one variable that is cxplained by the other and the level of significance of the relationship is given in parentheses. $\Lambda$ n $R^{2}$ of 1.0 indicates a perfect relationship. NS implies that $R^{2}$ was not significant at any acceptable level.
}

nous ( $R^{2}=0.247$, significant at the $99 \%$ level; Table 2$)$. From $A D 1500$ to $\approx 1700, A_{\mathrm{n}}$ increased slightly at both sites after which $A_{\mathrm{n}}$ decreased to a minimum at 1750 . This minimum is more pronounced at Dyer Plateau than at Siple Station. Since $1750, A_{n}$ has increased gradually at both sites although more strongly at Dyer Plateau than at Siple Station. This net accumulation increase since 1750 is in general agreement with those on James Ross and Dolleman Islands (sce Peel, 1992; Jones and others, 1993). As noted by Jones and others (1993), in this region, the $\delta^{18} \mathrm{O}$ and $A_{\mathrm{n}}$ histories are not correlated as expected assuming precipitation increases with temperature. 'The $\delta^{18} \mathrm{O}$ and $A_{\mathrm{n}}$ records from both Dyer Plateau and Siple Station further support this inconsistency; specifically, an isotopically cool period $(\approx 1800-1930$ ) is associated with increasing net accumulation. This pattern, apparently widespread in the peninsula, indicates a more complex relationship among moisture sources, atmospheric temperature and humidity, and net snow accumulation than is commonly assumed. As the peninsula is a metcorologically complex region, it poses a great challenge for accurate interprctation of ice core proxy data.

\section{Dust content and excess sulfate}

The 480 year histories of dust deposition at Dyer Plateau and Siple Station (Fig. 6) are quite similar $\left(R^{2}=0.475\right.$, significant at the $99.9 \%$ level; Table 2 ) with consistently low concentrations from AD 1500 until the mid-19th century There are two prominent dust features at both sites: 1 the gradual increase in dust content since 1850 and (2) the prominent dust event from 1598 to 1600 . The increase in dust since 1850 is perplexing in view of the concurrent decrease in temperature $\left(\delta^{18} \mathrm{O}\right)$ and increase in net accumulation. These observations raise the question whether the increased dust reflects: (1) a more dusty 


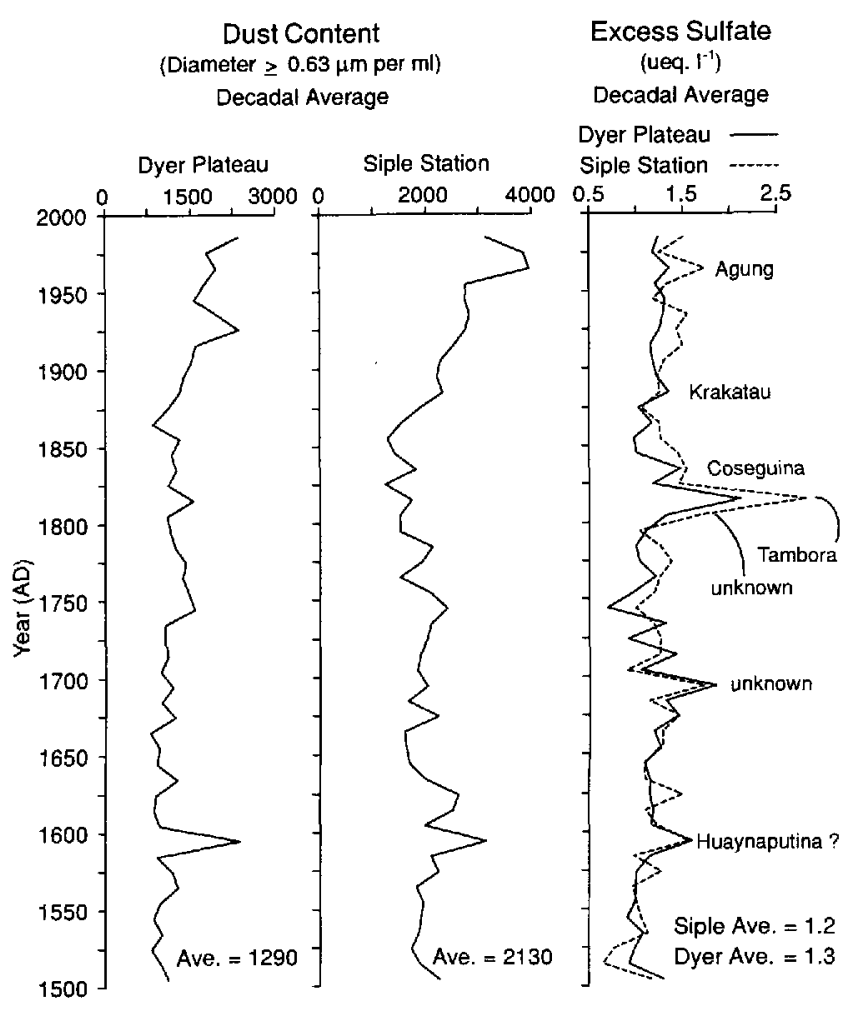

Fig. 6. Decadal averages of total dust content (diameters $\geq 0.63 \mu \mathrm{mm} \Gamma^{-1}$ ) and excess sulfate (EXS) on Dyer Plateau are illustrated with concurrent histories from Siple Station located at the base of the Anlarctic Peninsula.

atmosphere, resulting from (a) more effective entrainment processes, (b) increased source area as ice retreat in the peninsula region exposed more bedrock or (c) a semipermanent displacement of primary circulation features which resulted in the southward advection of dust, and/or (2) entrainment of dust in the more porous upper firn layers during drilling and transportation. The lack of a similar increase in the concentrations of the three major anions $\left(\mathrm{Cl}^{-}, \mathrm{SO}_{4}{ }^{2}\right.$ and $\left.\mathrm{NO}_{3}{ }^{-}\right)$suggests that the dust increase is probably not associated with contamination but does reflect a real increase in atmospheric dustiness.

As particulates are deposited by both wet and dry processes, it is difficult to separate their contributions without a continuous, multi-year, in situ snow and air sampling program. Previous studies in East Antarctica (Mosley-Thompson, 1992) and South America (Thompson and others, 1986) reported incrcased particulate deposition during cooler periods.

The second prominent dust feature is an abrupt and large dust increase from 1598 to 1600. In 1599, dust content increased by nearly a factor of 10 at both Dyer Plateau and Siple Station. Figure 6 also illustrates for both cores the excess sulfate (EXS) or non-sea-salt sulfate (NSS), adjusted using $\mathrm{C}_{1}{ }^{-}$to estimate the sea-salt component (Dai and others, 1991). EXS is substantially elevated from 1599 to 1601 , suggesting that the sulfate arrived at both sites 1 year after the particulates. The origin of this event is unknown. Although the 1600 eruption of Huaynaputina in southern Peru is prominent in the Quelccaya rccords (Thompson and others, 1986) and has been noted in EXS in Greenland (these authors) it is unlikely that these particulates originated from
Huaynaputina. Given the large concentrations, their origin is probably local. It is possible that Huaynaputina contributed to the elevared FXS in 1601 but it cannot be the source for EXS which first arrived in 1598. Huaynaputina has yet to be identified conclusively in Antarctic ice-core records. Ascertaining whether the dust is of volcanic origin is a logical next step as well as inspecting other Antarctic records for this potential "marker horizon". The EXS histories from Dyer Plateau and Siplc Station $\left(R^{2}=0.583\right.$, significant at the $99.9 \%$ level; Table 2) along with EXS histories from Greenland will contribute to the development of a global volcanic history for the last five centuries.

The EXS histories for Siple Station and Dycr Platcau (Fig. 6) reveal a number of known volcanic events as well as some unidentified events. Identification of known events provides time-scale confirmation. In addition, the recent background concentration of EXS may be compared with that from the pre-industrial era to determine whether Antarctic snow is yet contaminated by Northern Hemisphere industrial activities. To make this comparison, years of known volcanism (Fig. 6) were removed from the record prior to averaging. In the Dyer Platcau core the ratio of excess $\mathrm{SO}_{4}{ }^{2-}$ from 1851 to 1990 to that from 1600 to 1850 is $1.18 / 1.15$ ( $\mu \mathrm{eq} \mathrm{L} \mathrm{L}^{-1}$ ) suggesting virtually no change in the EXS source since 1850. A similar calculation for $\mathrm{EXS}$ at Siple Station gives a ratio of $1.32 / 1.24$, indicating a slight increase in EXS since 1850; however, this difference $\left(0.09 \mu \mathrm{eq} \mathrm{L}^{-1}\right)$ is very near the analytical precision of the analyses and may be meaningless.

\section{CONCLUSIONS}

The emerging palcoclimate history from Dyer Plateau is providing further insight into the regional history of the Antarctic Peninsula. When viewed along with a comparable history from Siple Station, certain regional characteristics become evident. These include relatively normal conditions (e.g. no LIA) from 1500 to 1850 with cooler conditions from 1850 to the mid-20th century. Cooler conditions were associated with a gradual increase in the flux of insoluble dust and an increase in nct accumulation. No major increase in excess sulfate aerosols is found which suggests no anthropogenic contribution to snow in this region.

The prominent warming since 1950 on Dyer Plateau is consistent with other obscrvations in the region, particularly those on the western side of the peninsula. This warming in the last few decades is not evident in $\delta^{18} \mathrm{O}$ histories from the East Antarctic plateau. These regional differences are not unlike those one would find in the meteorological historics of globally dispersed stations. A comparison of the decadal averages for the last 500 years from different ice cores reveals marked differences.

Figure 2 in Thompson and others (1993) compares five such histories: Camp Century, Greenland; Dunde ice cap, China; Quclccaya icc cap, Peru; and Siple and South Pole Stations, Antarctica. These five, in addition to the Dyer Plateau record presented here and another record emerging from the Guliya ice cap in western China (Thompson and others, 1993; and unpublished data), reveal that the recent warming has becn most pro- 
nounced at the high elevation, non-polar sites (Dunde, Guliya and Quelccaya ice caps) and in the Antarctic Peninsula. Up to 1980 , no warming was evident at the South Pole. At Siple Station the cooler conditions in the last century have becn replaced by a warming trend in the last two decades which is rising just above the longterm average. Thus, the recent "globally averaged warming" is not cvident at all latitudes. These ice-core histories are particularly valuable as they provide a longer-term perspective from which the significance of any recent changes may be evaluated.

\section{ACKNOWLEDGEMENTS}

We thank the personnel from the Byrd Polar Research Center and the British Antarctic Survey who participated in the field program, and Bruce Koci of the Polar Ice Coring Office (PICO) which is supported under a contract from the U.S. National Science Foundation. Wc gratefully acknowledge the logistical support by the staff and BAS Air Unit at Rothera Station. K. Doddroe typed the manuscript and J. Nagy prepared the figures. This project was supported by U.S. National Science Foundation grants DPP-8716384 and ATM-90084-7 to The Ohio State University and U.S. National Science Foundation grant IPPP-8716243 to the University of Washington, and support to the British Antaretic Survey was provided by the U.K. Natural Environment Research Council. We thank P. D. Jones for his insightful comments and valuable suggestions. This is contribution Number 872 of the Byrd Polar Research Genter.

\section{REFERENCES}

Aristarain, A.J., J. Jouzel and M. Pourchet. 1986. Past Antarctic: Peninsula climate $(18501980)$ deduced from an ice core isotope record. Chimatic Change, 81 (1), 69-89.

Bradley, R.S. 1985. Quatemary Paleotimatology: methods of paleocimatic reconstruction. Boston, Allen and Lnwin.

Crozaz, G. 1969. Fission products in Antarctic snow. An additional reference level in January 1965. Earth Planet. Sci. Lett., 6i 1), 6-8.
Dai, J., E. Mosley-Thompson and L.G. Thompson. 1991. Ice corc cridence for an explosive tropical volcanic cruption 6 years preceding Tambora. 7. Geophys. Res., 96 (D9), 17,361-17,366.

Dansgaard, W., S.J. Johnsen, H. B. Clausen and N. Gundestrup. 1973. Stable isotope glaciology. Medd. (ron., 197 2), 1-53.

Doake, C.S. M. and I). (s. Vaughan. 1991. Rapid disintegration of the Wordie Ice Shelf in response to atmospheric warming. Vature, $\mathbf{3 5 0}(6316), 328330$.

Johnsen, S.J. and 9 others. 1992. Irregular glarial interstadials recorded in a new Greenland ice core. Fature, $\mathbf{3 5 9}(6393), 311313$.

Jones, P D., R. Marsh, T. M. L. Wigley and D. A. Peel. 1993. Decadal timescale links between Antarctic Peninsula icc-core oxygen-18, deuterium and temperature. The Holocene, 3 1), 11-26.

Jouzel, J., L. Merlivat, J.R. Pctit and C. Lorius. 1983. Climate information over the last century deduced from a detailed isotopic record in the South Polc snow. 7. Geophy. Res., 88 C4), 2693-2703.

Mosley-Thompson, E. 1992. Paleoenvironmental conditions in Antarctica since A.D. 1500: ice core evidence. In Bradley, R.S. and P. D. Jones, eds. Climate since A.D. 1500. London, Routledge, 572-591.

Moslev-Thompson, E., I. G. Thompson, P. Grootes and N. Gundestrup. 1990. Little Ice Age (Neoglacial paleuenvironmental conditions at Siple Station, Antarctica). Ann. Glaciol, 14, 199-204.

Mosley-'Thompson, E., J. Dai, L. G. 'Thompson, P. M. Grootes, J. K. Arbogast and J. F. Paskievitch. 1991. Glaciological studies at Siple Station (Antarctica): potential ice-core paleoclimatic record. 7. Glaciol, 37 (125), 11-22.

Pcol, D. A. 1992. Ice corc evidence from the Antarctic Peninsula region. In Bradley, R. S. and P. D. Jones, eds. Climale since A.D. 1500. London, Routledge, 549-57].

Picciotto, F. E. and S. E. Wilgain. 1963. Fission products in Antarctic snow: a reference level for measuring accumulation. 7 . Geophys. Res., 68(21), 5965-5972.

Schwcrdtfeger, W. 1984. Weather and climate of the Antartic. Amsterdam. Elsevier.

Splettstoesser, J. 1992. Antarctic global warming. Nature, 355(6360), 503. Thompson, L. G. 1977. Microparticles, ice sheets and rlimate. Ohio State University, Institute of Polar Studies Report 64.

Thompson, L. G., E. Mosley-Thompson, W. Dansgaard and P. M. Grootes. 1986. The Little Ice Age as recorded in the stratigraphy of the tropical Quelccaya icc cap. Science, 234(4774), 361-364.

Thompson, L. G. and 9 others. 1989. Holocene-Late Pleistocene climatic ice core records from Qinghai-Tibetan Plateau. Science, 246 4929 i. 174477 .

Thompson, L. G. and 6 others. 1993. Recent warming: ice core cvidence from tropical ice cores with emphasis on central Asia. Global Planet. Change, 7, 145156.

The accuracy of references in the text and in this list is the responsibility of the authors, to whom queries should be addressed. 